\title{
Comparative results between bone marrow culture and blood culture in the diagnosis of Typhoid fever
}

Eddy Soewandojo*, Suharto, Usman Hadi, P. Fans, Prihartini^

\begin{abstract}
Abstrak
Penggunaan antibiotika yang luas dan dini pada demam telah mengubah manifestasi demam tifoid di Indonesia. Gambaran klasik yang dibaca dari buku teks sekarang jarang dijumpai. Tujuan dari penelitian ini ialah untuk membandingkan biakan sumsum tulang dan biakan darah dalam diagnosis demam tifoid. Sampel diambil dari darah dan sumsum tulang pasien yang dirawat di bangsal penyakit tropik RSU Dr. Sutomo, Surabaya dengan gambaran klinis demam tifoid dan berusia lebih dari 13 tahun. Diagnosis klinis ditegakkan berdasarkan: riwayat demam lebih dari 5 hari, disertai dengan adanya demam tinggi $\left(>38^{\circ} \mathrm{C}\right.$ ) di RS (diagnosis esensial) dan kombinasi sedikitnya 6 dari hal berikut: tinggal di daerah endemis tifoid; dengan riwayat keluarga demam tifoid; demam tidak turun setelah sebab-sebab lain yang menyebabkan demam yang berkelanjutan disisihkan; hepatomegali, doughy abdomen; ileus; peningkatan protein C-reactive; lekositosis atau lekopeni dan adanya komplikasi spesifik dari tifoid misalnya perforasi usus. Penelitian ini dilakukan sejak pertengahan Mei 1997 sampai pertengahan Oktober 1997. Hasilnya: sampai pertengahan Juli 1997, terkumpul 21 sampel. Dari sampel tersebut, 16 sampel sumsum tulang positif, terdiri dari 13 isolat S. typhi, 3 isolat S. paratyphi A. Jika dibandingkan dengan kultur darah, hanya ada 1 sampel biakan darah negatif sementara biakan sumsum tulang positif S. typhi. Sebaliknya ada 1 biakan darah positif sedangkan biakan sumsum tulang negatif. Di antara 14 biakan darah/sumsum tulang yang positif, tiga sampel diambil dari pasien tifoid dengan komplikasi (2 dengan manifestasi susunan saraf pusat, 1 perforasi usus halus). Berdasarkan analisis statistik, tidak terdapat perbedaan bermakna antara hasil biakan sumsum tulang dan biakan darah dalam diagnosis demam tifoid. Kesimpulan: pada biakan sumsum tulang pertumbuhan bakteri lebih cepat terdeteksi jika dibandingkan dengan biakan darah, namun tidak terdapat perbedaan bermakna dalam diagnosis demam tifoid.
\end{abstract}

\begin{abstract}
The early, wide use of antimicrobial agents in febrile disease has changed the clinical manifestations of typhoid fever (TF) in Indonesia. The classical textbook picture is now rarely observed. The aim of the study is to compare bone marrow culture and blood culture in the diagnosis of TF. Samples were obtained from patients (>13 years old) admitted to tropical ward Dr. Sutomo General Hospital Surabaya with clinical picture of $T F$, and blood and bone marrow culture were performed. Clinical diagnosis of TF was made on the basis of: a history of fever ( $>5$ days) plus the documentation of high fever $\left(>38^{\circ} \mathrm{C}\right.$ ) in the hospital (essential diagnosis) and the combination of at least six of the of the following : residence in a known typhoid endemic area; a family history of typhoid; the failure of fever to resolve after the exclusion of other cause of prolonged fever; hepatomegaly, doughy abdomen; abdominal ileus; an elevated level of $C$-reactive protein; leucocytosis or leucopenia and documentation of specific complication of typhoid e.g. intestinal perforation. This study was conducted from mid May 1997 to mid October 1997. Result : Until mid July 1997, we collected twenty-one samples. From those samples, sixteen samples of bone marrow culture were positive, consisted of thirteen positive $\mathrm{S}$. typhi and three positive S. paratyphi A. In comparison with blood culture, there's only one sample of blood culture negative, in which bone marrow culture was positive for $\mathrm{S}$. typhi, but on the contrary there's one blood culture positive for $\mathrm{S}$. typhi while bone marow culture was still negative. Among fourteen blood/bone marrow culture positive S. typhi, three samples came from complication of typhoid ( 2 CNS manifestations, 1 small bowel perforation). Based on statistical analysis, there is no significant difference between bone marrow culture and blood culture results in the diagnosis of TF. Conclusion: bone marrow culture showed positive growth faster than blood culture but made no significant difference in the diagnosis of $T F$,
\end{abstract}

\footnotetext{
*Tropical and Infectious Disease Division,

Department of Internal Medicine;

^Department of Clinical Pathology,

Dr. Sutomo General Hospital, Surabaya, Indonesia
} 